Matgorzata Grzegorczyk

\title{
Typy relacji i rodzajów ryzyka występujących w modelach transferu wiedzy i komercjalizacji akademickich innowacji na przykładach uczelni różnych krajów
}

\section{Wstęp}

Pomimo że działania Europy w zakresie innowacyjności poprawiają się z roku na rok, powiększa się zróżnicowanie poziomu innowacyjności wśród państw członkowskich. Niektóre nowe państwa członkowskie, jak Estonia, Litwa i Łotwa, odnotowały w latach 2008-2013 największy wzrost innowacyjności, z Estonią jako niekwestionowanym liderem wzrostu innowacyjności (7,1\%), podczas gdy Polska i Bułgaria miały najniższe z dodatnich stóp wzrostu innowacji (odpowiednio 0,4 i $0,6 \%)^{1}$. Polska wypada bardzo słabo na tle innych krajów europejskich i jest zaliczana, obok Łotwy, Rumunii, Bułgarii, Macedonii i Turcji, do najsłabszych innowatorów w UE. Co więcej, tempo rozwoju innowacyjności zmieniło się w przypadku zaledwie dwóch członków UE: Litwy (poprawa sytuacji i przejście do grupy średnio zaawansowanych innowatorów, moderate innovators) oraz Polski (pogorszenie sytuacji i spadek do grupy słabych innowatorów, modest innovators). Konieczne jest zatem przemyślenie głównych modeli konceptualizacji innowacji, aby lepiej uchwycić interakcje pomiędzy kluczowymi podmiotami tworzącymi, zgodnie z koncepcją triple helix ${ }^{2}$ system innowacyjności: uczelniami, biznesem i władzami państwowymi.

${ }^{1}$ Innovation Union Scoreboard 2013 - raport Komisji Europejskiej, http://ec.europa.eu/enterprise/policies/innovation/policy/innovation-scoreboard/index_en.htm.

${ }^{2}$ H. Etzkowitz, L. Leydesdorff, The endless transition: A 'triple helix' of university-industry-government relations, „Minerva” 1998, No 36, s. 203-208; M. Ranga, H. Etzkowitz, 'Triple helix systems: an analytical framework for innovation policy and practice in the knowledge society, „Industry and Higher Education” 2013, No 27 (4), Special Issue. 


\section{Rola uczelni w procesach integracji z biznesem}

Innowacyjność przedsiębiorstw zwiększa się, gdy podejmują one współpracę z innymi jednostkami, zwłaszcza w zakresie badań i rozwoju. Współpraca ta jest jednocześnie traktowana jako istotne źródło innowacji³. W Polsce firmy borykają się z wysokimi kosztami innowacji, przy jednoczesnym braku kapitału i ograniczonych możliwościach pozyskiwania go z zewnątrz. Współpraca pomiędzy światem nauki a firmami praktycznie nie istnieje. Świadomość firm odnośnie do możliwości korzystania z zasobów naukowych i rozwoju dla rozwoju firmy i innowacji jest niska, innowacyjność ma charakter imitacyjny (kopiowanie zachodnich rozwiązań) i dominuje model rozwoju poprzez zakup nowych maszyn i urządzeń.

Współpraca uczelni z biznesem jest procesem współtworzenia innowacji, w którym transfer wiedzy i wyników badań powinien być rozumiany jako główna misja uczelni ${ }^{4}$. Dynamika innowacji i ich skala zależą głównie od umiejętności korzystania z osiągnięć nauki i możliwości jej dystrybucji. Wyzwaniem jest zamiana wiedzy naukowej i technicznej w nowe produkty i usługi dostępne oraz akceptowane przez klientów na rynkus.

W krajach będących najsłabszymi innowatorami w Europie uniwersytety funkcjonują przede wszystkim jako instytucje koncentrujące się na nauczaniu, przy jednoczesnym niskim poziomie badań naukowych i działań przedsiębiorczych (patenty, licencje, tworzone firmy itp.). Dodatkowo funkcjonują w otoczeniu firm o słabych zdolnościach badawczo-rozwojowych, niewystarczających wydatków budżetowych i prywatnych na $\mathrm{R} \& \mathrm{D}$, brakach kapitału wysokiego ryzyka i wielu barier strukturalno-systemowych. Sektor naukowy i badawczo-rozwojowy w Polsce nie realizuje skutecznie funkcji w zakresie transferu wyników badań do przemysłu. Poszczególne ogniwa systemu: biznes, nauka, jednostki B \& R działają w izolacji, niewiele wiedzą nawzajem o swojej ofercie i potrzebach pozostałych członków systemu. Zidentyfikowano szereg barier transferu i komercjalizacji wiedzy ${ }^{6}$ :

${ }^{3}$ J. Mairesse, P. Mohen, To be or not to be innovative: an exercise in measurement, NBER Working Paper 2001, No 8644.

${ }^{4}$ Deklaracja lizbońska, Uczelnie Europy po 2010 roku: różnorodność ze wspólnym celem, http://www.bwm.pk.edu.pl/Deklaracja_Lizbonska.pdf.

${ }_{5}^{5}$ D. Trzmielak, M. Grzegorczyk, Technology marketing - the use of relationship marketing principles in the process of international commercialization, [w:] Rozvoj marketingu v teórii a praxi Marketing Development in Theory and Practice, red. J. Striss, EDIS - Vydavatel'stvo Žilinskej Univerzity, Žilina 2010, s. 227-233.

${ }_{6}$ System transferu technologii i komercjalizacji wiedzy w Polsce - sity motoryczne i bariery, red. K. Matusiak, J. Guliński, PARP, Warszawa 2010, s. 12. 
- instytucjonalne - wynikające z niewłaściwej struktury podmiotowej rynku;

- systemowe - niemobilizujący sektor badawczy do innowacyjnego rozwoju, a jednocześnie zdominowany nadmierną liczbą aktów prawnych i regulacji,

- świadomościowo-kulturalne - obejmujące niską akceptację społeczną dla innowacji przy jednocześnie wysokiej samoocenie relacji nauka-biznes,

- kompetencyjne - hamujące sprawne działania transferu wyników badań z ośrodków naukowo-badawczych do przemysłu ze względu na niekompetencję władz, jednostek samorządu terytorialnego i administracji wyższych uczelni, a także początkujących przedsiębiorców.

W polskich uczelniach wyższych transfer wiedzy i technologii realizowany jest zazwyczaj za pomocą jednostek transferu technologii, które przybierać mogą różne formy rozwiązań organizacyjnych. Do najczęściej spotykanych należą akademickie inkubatory przedsiębiorczości oraz biura lub centra transferu technologii . Najpowszechniejszy model to centrum transferu technologii jako jednostka wewnętrzna administracyjna uczelni, skupiająca się głównie na licencjonowaniu. Funkcja ta w większości uczelni jest funkcją wewnętrzną, jednak spotyka się sytuacje zakupu niektórych usług z zewnątrz (outsourcing). Inny model to zewnętrzny podmiot, który zarządza własnością intelektualną uczelni w jej imieniu (model ten funkcjonuje także w brytyjskim Oxford University - ISIS Innovation). Transfer wiedzy jest także realizowany poprzez jednostki rozwoju biznesu, których głównym celem jest tworzenie jak największej liczby powiązań pomiędzy światem akademickim a światem biznesu oraz pozyskiwanie i zwiększenie nakładów biznesu na badania. Często spotykany jest także model partnerskiej współpracy w ramach parku naukowego, gdzie głównym celem, obok licencjonowania, jest przyciąganie i utrzymywanie firm w parku naukowym, który jest w całości lub częściowo własnością uczelni (przykład parku naukowego w brytyjskim Warwick).

\section{Rola relacji w procesach transferu wiedzy i komercjalizacji wyników badań}

Marketing relacji jest koncepcją, według której skuteczność rynkowa firm zależna jest od nawiązania partnerskich stosunków z uczestnikami rynku. Koncepcja ta zakłada budowę związków lojalnościowych z klientami i aliansów stra-

${ }^{7}$ Wyniki badania „Integracja i transfer wiedzy z organizacji naukowych i badawczych do przedsiębiorstw". Projekt został sfinansowany ze środków Narodowego Centrum Nauki przyznanych na podstawie decyzji numer DEC-2011/01/B/NS4/05200. 
tegicznych z partnerami w biznesie ${ }^{8}$. W przypadku firm i działaności biznesowej relacje te będą obejmować zarówno klientów końcowych, jak i dostawców, pośredników, konkurentów, pracowników, organizacje administracji państwowej, organizacje non-profit. Inni autorzy również wskazują, że skuteczność firmy i jej efektywność finansowa zależą od jakości nawiązywanych relacji rynkowych ${ }^{9}$. Przenosząc założenia marketingu relacji na procesy transferu wiedzy i komercjalizacji należałoby przyjąć, iż skutecznośc uczelni w zakresie komercjalizacji, mierzona liczbą patentów, listów intencyjnych, licencji, założonych firm, zależy od jakości nawiązywanych $\mathrm{w}$ tym procesie relacji. W tym przypadku relacje będą obejmowały: firmy, instytucje otoczenia innowacyjnego biznesu (parki naukowe, inkubatory, centra transferu technologii), instytucje państwowe związane z rozwojem badań naukowych i rozwojowych (NCBiR, NCN), różne jednostki administarcji uczelnianej (rektor odpowiedzialny za współpracę z biznesem, jednostki odpowiedzialne za współpracę z biznesem i komercjalizację, poszczególne wydziały, zespoły badawcze, pracownicy).

Podejście takie potwierdza wielu praktyków zajmujących się wdrażaniem innowacji akademickich na rynek w krajach o najwyższych wskaźnikach innowacyjności. „Największą wartością jaką możemy zaoferować nowej innowacyjnej firmie w parku, obok powierzchni biurowych lub laboratoryjnych, doradztwa i wspracia merytorycznego jest sieć kontaktów. Tworzymy środowisko sprzyjające spotkaniom, wymianie myśli, wdrażając ideę open innovation. Wychodzimy z założenia, że dzielenie sie wiedzą i pomysłami generuje nowe idee i kolejne innowacje. [...] Ponadto jeżeli mam w parku małą firmę, która właśnie stworzyła aplikację ułatwiającą komunikację telefonu z lodówką i mam w parku firmę Ericsson, to łatwiej jest mi sprzedać tę innowację niż gdybym nie miał w parku Ericssona" 10 - mówi dyrektor największego szwedzkiego parku naukowego, który generuje ok. 80-90 nowych firm (start-up) rocznie. Podobne podejście dostrzega się w Stanach Zjednoczonych, gdzie networking traktowany jest jako podstawa rozwoju biznesu ${ }^{11}$. Organizuje się specjalne spotkania (reception), na których prezentowane są różne pomysły na biznes, generowane przez naukowców, studentów, indywidualnych innowatorów, firmy z inkubatorów. Spotkania mają charak-

${ }^{8}$ M. Rydel, C. Ronkowski, Marketing partnerski, „Marketing i Rynek” 1995, nr 9, s. 5.

9 J. Otto, Marketing relacji. Koncepcja i stosowanie, C.H. Beck, Warszawa 2004, s. 54.

${ }_{10}$ Wywiad z H. Mollerem, dyrektorem Ideon Science Park w Lund w Szwecji, przeprowadzony w ramach wizyty studyjnej w Lund University, 2013, finansowanej ze środków EU.

${ }^{11}$ Informacje zebrane w trakcie wizyty badawczej w USA, w ramach badania „Integracja i transfer wiedzy z organizacji naukowych i badawczych do przedsiębiorstw”. Projekt został sfinansowany ze środków Narodowego Centrum Nauki przyznanych na podstawie decyzji numer DEC$-2011 / 01 / \mathrm{B} / \mathrm{NS} 4 / 05200$. 
ter nieformalny, często odbywają się na stojąco z lampką wina w ręku. Celem jest szybka prezentacja idei, zebranie informacji zwrotnych, nawiązanie kontaktów, wymiana opinii, generowanie nowych pomysłów. Każda opinia jest istotna, gdyż może być inspiracją do dalszych działań. Podobnie każdy nowy kontakt jest ważny, gdyż nawet jeśli nie wnosi nic nowego do rozwiązania, generuje kolejne kontakty aż do nawiązania relacji, których efektem będzie wprowadzenie produktu na rynek (w tym relacji z inwestorami) ${ }^{12}$. Znaczenie networking $u$ docenia się także w Wielkiej Brytanii, choć tam spotkania przedstawicieli uczelni i firm mają charakter zdecydowanie bardziej formalny. Dla przykładu centrum inowacyjności Uniwersytetu Oksfordzkiego - ISIS Innovation University of Oxford - organizuje spotkania, na które zapraszani są inwestorzy i przedsiębiorcy oraz innowatorzy i naukowcy. Spotkania są ustalane z dużym wyprzedzeniem czasowym, często mają charakter eleganckiej kolacji, zwykle odbywają się w eleganckich miejscach, obowiązuje strój wieczorowy, przygotowywane są według ściśle określonych procedur, a udział w nich jest płatny.

\section{Typy relacji w procesach transferu wiedzy i komercjalizacji}

Relacje zwykło się traktować w kategorii związku pomiędzy dwoma stronami, w przypadku komercjalizacji wiedzy - uczelnią i biznesem. Jednak w praktyce innowacje są rezultatem licznych złożonych interakcji zachodzących między jednostkami, organizacjami i środowiskiem, w którym działają. Badając modele relacji w procesach transferu wiedzy należy uwzględnić złożoność komunikacji i współpracy wynikającą z różnorodności relacji i partnerów. Skuteczna komercjalizacja obejmuje tworzenie relacji pomiędzy poszczególnymi graczami: osobami reprezentującymi uczelnię i naukowcami, firmami, klastrami, parkami naukowo-technologicznymi, inkubatorami, ekspertami w dziedzinie wynalazku, urzędami unijnymi, krajowymi i lokalnymi, inwestorami oraz venture capital. Warto zwrócić uwagę na złożoność relacji w samej uczelni macierzystej dla wynalazku. W praktyce przedsiębiorca nie kontaktuje się z reprezentacją uczelni (,uczelnia jako organizacja mówiąca jednym głosem”), a z różnymi jej przedsta-

${ }^{12}$ Spotkania takie organizują m.in. Uniwersytet Teksański w Austin (UT), Uniwersytet Stanforda, Uniwersytet Berkley, Uniwersytet Kalifornijski, Centrum Medyczne Uniwersytetu Teksańskiego w Houston, Centrum Nauk Medycznych Uniwersytetu Teksańskiego w San Antonio, Uniwersytet Pólnocnej Karoliny. Inicjatorami i promotorami innowacyjnych przedsięwzięć zwykle są instytucje wsparcia biznesu, takie jak: inkubatory uczelniane, inkubatory regionalne należące do miasta, współpracujące z uczelniami, centra transferu technologii na uczelni, instytucje rozwoju innowacyjności, np. IC2 Institute. 
wicielami: władzami, jednostkami odpowiedzialnymi za komercjalizację na uczelni, np.: centrum transferu technologii, inkubator, działy współpracy z biznesem, naukowcami i zespołem badawczym (zob. rys. 1).

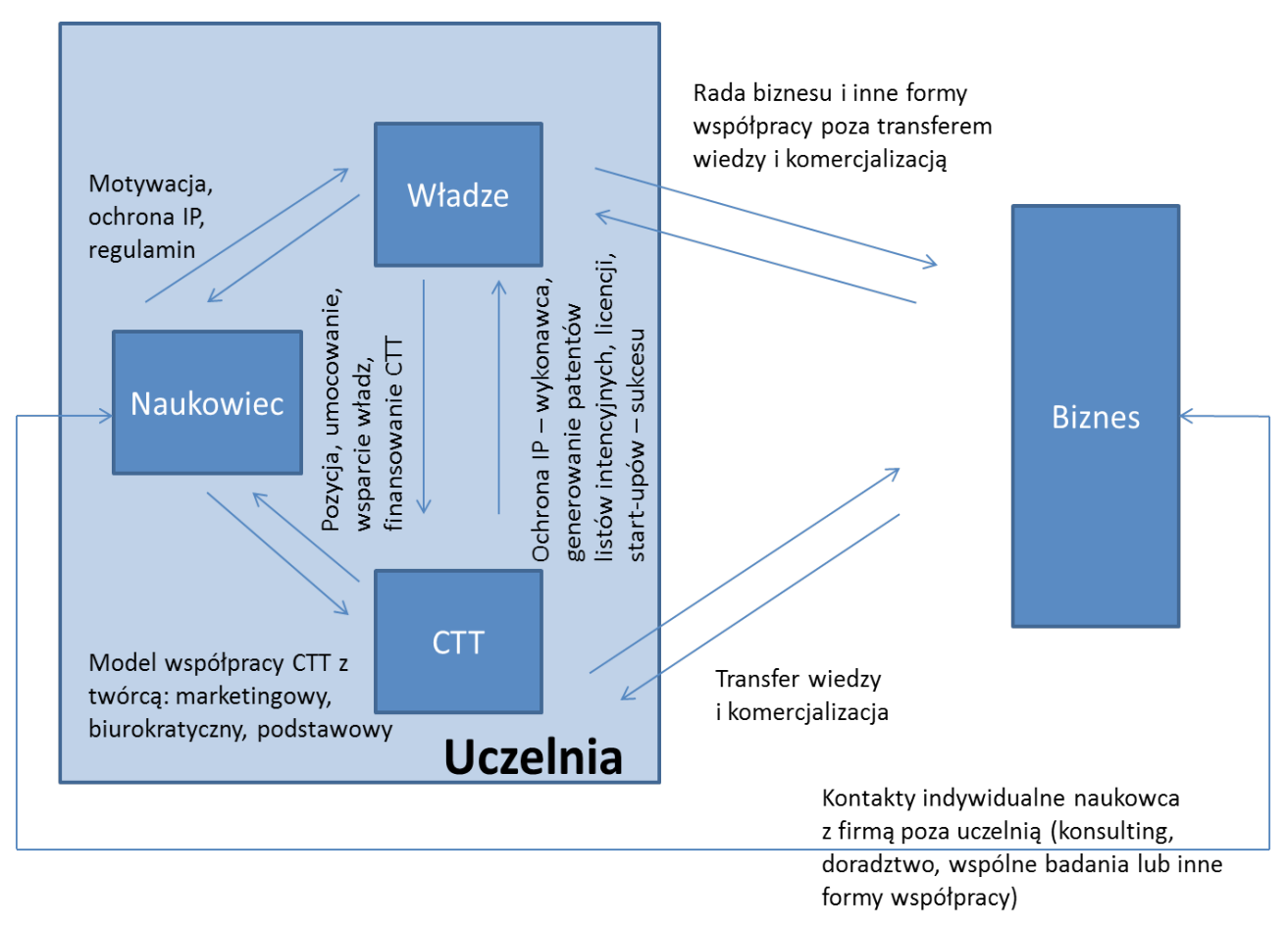

Rysunek 1. Złożonośc relacji w procesach transferu wiedzy

Źródło: opracowanie własne.

Cele i priorytety naukowca mogą się znacznie różnić od celów uczelni jako instytucji, co więcej w wielu sytuacjach pojawia się relacja pomiędzy naukowcem a firmą poza uczelnią. W regionie Houston, gdzie na rynku występuje wiele uczelni medycznych i wiele korporacji działających w obszarze biotechnologii, które również prowadzą własne prace badawczo-rozwojowe, wręcz wymaga się od pracowników naukowych uczelni indywidualnych powiązań z biznesem. Są one istotnym kryterium $\mathrm{w}$ procesie rekrutacji naukowców do pracy na uczelni. Podobne podejście dostrzega się na Uniwersytecie Stanforda, gdzie zakłada się, że to naukowiec odgrywa największą rolę w procesie promowania swoich wyników badań oraz inicjowania relacji z biznesem ${ }^{13}$. Badania wyraźnie wskazują, że

${ }^{13}$ R.C. Miller, B.J. Le Boeuf, Developing University - Industry Relations. Pathways to Innovation from the West Coast, John Wiley \& Sons, San Francisco, 2009, s. 8. 
organizacje uczą się nawzajem od siebie w największym stopniu poprzez wymianę wiedzy pomiędzy indywidualnymi osobami, a nie poprzez formalne mechani$z y^{14}$. Dotyczy to dyfuzji idei i wiedzy zarówno w relacjach pomiędzy ośrodkami naukowymi i badawczymi, jak i pomiędzy firmami. Rolę indywidualnych osób $\mathrm{w}$ tworzeniu pomostów między organizacjami podkreśla wielu autorów ${ }^{15}$.

W kontekście komercjalizacji struktura sieci relacji jest bardzo złożona. Istnieje duża liczba uczestników i osób, które współdziałają nie z jedną, lecz z kilkoma partnerami. Złożoność tych relacji wynika z różnych celów i motywów współdziałania, różnych kultur organizacyjnych, struktur, strategii, doświadczenia, preferowanego stylu komunikacji i sposobu działania ${ }^{16}$. Przykładem niezwykle złożonej sieci współzależności może być park naukowy w Tromso w Norwegii ściśle współpracujący z Uniwersytetem Tromso.

Duża liczba oraz różnorodność relacji generuje wiele problemów komunikacyjnych i prowadzi do utraty informacji wśród powiązań bezpośrednich i pośrednich. Szybka i skuteczna komunikacja jest szczególnie istotna w przypadku przełomowych wynalazków, ponieważ liczba możliwych ścieżek komunikacji pomiędzy graczami procesu komercjalizacji może rosnąć geometrycznie wraz ze wzrostem liczby uczestników procesu ${ }^{17}$. Wysoki stopień niepewności i ryzyka w rozwoju technologii podkreśla znaczenie zaufania i cech budujących wiarygodność partnerów.

Rozważania i badania w dziedzinach socjologii, antropologii społecznej i psychologii społecznej doprowadziły do wyodrębnienia czterech form relacji międzyludzkich o charakterze fundamentalnym, ogólnym, elementarnym i uniwersalnym ${ }^{18}$. Są nimi:

${ }^{14}$ S. Shane, Technology and innovation management, John Wiley \& Sons, West Sussex, 2008, s. 353.

${ }^{15}$ D. Crane, Invisible colleges. Diffusion of knowledge in scientific communities, University of Chicago Press, Chicago 1972; M.A. Rappa, K. Debackere, Technology communities and the diffusion of knowledge, „R \& D Management” 1992, vol. 22(3), s. 209-220; T.R. Madanmohan, S. Navelkar, Roles and knowledge management in online technology communities: an ethnography study, „International Journal of Web Based Communities” 2004, vol. 1(1), s. 71-89; M.E. Porter, Location, competition, and ecnonomic development: local clusters in a global economy, „Economic Development Quarterly" 2000, vol. 4 (1), s. 15-34.

${ }^{16} \mathrm{~K}$. Debackere, R. Veugelers, The role of academic technology transfer organizations in improving industry science links, ,Research Policy” 2005, vol. 34, issue 5, s. 321-342.

${ }^{17} \mathrm{~S}$. Robin, T. Schubert, Cooperation with public research institutions and success in innovation: evidence from France and Germany, Karlsruhe, April 2010, [w:] Innovation Systems and Policy Analysis, Fraunhofer ISI Discussion Papers 2010, No 24.

${ }_{18}$ A.P. Fiske, Relativity within moose culture: four incommensurable models for social relationships, „Ethos”1990, vol. 18, s. 180-204. 
- wspólnota dzielenia (communal sharing) - oparta na jedności, wspólnocie, niezróżnicowanej tożsamości, życzliwości, zazwyczaj tworzona wśród bliskich krewnych;

- uszeregowanie oparte na autorytecie (authority ranking) - relacja asymetryczna, powszechnie wystepująca w hierarchii, połączona z wydawaniem rozkazów i okazywaniem szacunku;

- równoprawne dopasowanie (equality matching) - tzw. relacja one-to-one, w której jednostki sa odrębne, ale równe sobie, przejawiające jednakowy wkład i dystrybucję korzyści;

- wycena rynkowa (market pricing) - oparta na kalkulacji stosunku korzyści do poniesionych nakładów.

Relacje te różnią się pod względem formy (współzależność lub zależność) oraz głębokości (głębokie lub płytkie). Każdy rodzaj relacji powiązany jest z innym rodzajem ryzyka, np. niedyskrecją, nierzetelnością, zaniedbaniami, nadużyciami, oszustwami itd. (zob. tab. 1). Wszystkie wymienione ryzyka może obserwować w relacjach występujących pomiędzy uczestnikami procesów transferu wiedzy i komercjalizacji. W poszczególnych rodzajach relacji dominuje inny zestaw cech gwarantujących, że druga strona jest godna zaufania.

Tabela 1. Rodzaje relacji i związane z nimi ryzyka

\begin{tabular}{|l|l|l|}
\hline \multicolumn{1}{|c|}{ Rodzaj zależności } & \multicolumn{1}{|c|}{ Typ ryzyka } & \multicolumn{1}{|c|}{$\begin{array}{c}\text { Cechy } \\
\text { determinujące } \\
\text { wiarygodność }\end{array}$} \\
\hline Płytka zależność & $\begin{array}{l}\text { niedyskrecja - obawa, że istotne informacje nie } \\
\text { zostaną udostępnione; } \\
\text { nierzetelność - obawa, że druga strona nie zachowa } \\
\text { się zgodnie z oczekiwaniami }\end{array}$ & $\begin{array}{l}\text { dyskrecja } \\
\text { rzetelność } \\
\text { kompletność }\end{array}$ \\
\hline Głęboka zależność & $\begin{array}{l}\text { oszustwo wynikające z asymetrii posiadanej wiedzy; } \\
\text { nadużycie - osiągnięcie dodatkowych korzyści ko- } \\
\text { sztem drugiej strony } \\
\text { zaniedbanie - niedopilnowanie interesów drugiej } \\
\text { strony; } \\
\text { zagrożenie poczucia godności wynikające z postrze- } \\
\text { ganego braku sukcesu w związku }\end{array}$ & $\begin{array}{l}\text { spójuck } \\
\text { troska } \\
\text { życzliwość }\end{array}$ \\
\hline Płytka współzależność & $\begin{array}{l}\text { ryzyko towarzyszące płytkiej zalezności; } \\
\text { zła koordynacja - obawa, że koordynacja działań } \\
\text { będzie niewystarczająca lub zbyt wolna }\end{array}$ & $\begin{array}{l}\text { przewidywalnośćć } \\
\text { spójność }\end{array}$ \\
\hline $\begin{array}{l}\text { Głęboka } \\
\text { współzależność }\end{array}$ & $\begin{array}{l}\text { błędne przewidywanie - obawa, że bez } \\
\text { szczegółowych instrukcji jedna strona nie będzie } \\
\text { w stanie przewidzieć potrzeby drugiej strony relacji }\end{array}$ & $\begin{array}{l}\text { dalekowzrocznośćć } \\
\text { intuicja } \\
\text { empatia }\end{array}$ \\
\hline
\end{tabular}

Źródło: B.H. Shepard, D.M. Serman, The grammars of trust: A model and general implications, „The Academy of Management Review” 1998, vol. 23, No 3, s. 423, za: K. Dziewanowska, Relacje i lojalność klientów w marketingu, Wyd. Nauk. WZ UW, Warszawa 2012, s. 274. 
W procesie komercjalizacji firma zwykle występuje w charakterze klienta, nawet jeśli jest to relacja partnerska. Zatem obok wymienionych powyżej ryzyk związanych z charakterem relacji należy uwzględnić także ryzyka łączące się $\mathrm{z}$ procesem zakupu, w tym głównie ryzyko technologiczne oraz finansowe ${ }^{19}$.

\section{Zakończenie}

Wyzwania, jakie stawia nauce rynek są związane z optymalnym transferem idei do przemysłu i zamianą wiedzy naukowej i technicznej w usługi nowego produktu na akceptowalnym poziomie kosztów. Wymaga to zmiany podejścia uczelni i jednostek B+R do współpracy z firmami i zastosowania koncepcji marketingowych w procesie komercjalizacji kompetencji i wyników badań uczelni. W szczególności oznacza to zaś koncentrację na klientach - potencjalnych odbiorcach i użytkownikach wyników badań uczelni, włączając w to znajomość rynku i rozpoznanie potrzeb klienta, a także elementy kształtujące relacje uczelni z biznesem.

Podstawą komercjalizacji jest innowacyjne rozwiązanie jako źródło i narzędzie zarządzania wiedzą i know-how ${ }^{20}$. Natura technologii uniwersyteckich obejmuje rozwiązania na bardzo wczesnym etapie cyklu życia technologii i produktu $^{21}$, co generuje wysokie ryzyko niepowodzenia. Dodatkowo pojawiają się ryzyka wynikające $\mathrm{z}$ rodzaju relacji tworzonych w sieci powiązań występujących $\mathrm{W}$ procesie komercjalizacji. Biorąc pod uwagę fakt niskiego poziomu zaufania polskich przedsiębiorców do uczelni jako partnera biznesowego, wskazane są dalsze badania w zakresie cech determinujących wiarygodność relacji pomiędzy poszczególnymi uczestnikami procesów. Wiarygodność i zaufanie będą wpływały na siłę relacji i minimalizację pojawiającego się ryzyka.

\section{Bibliografia}

Betz F., Academic government industry strategic research relationships, „Journal of Technology Transfer" 1997, vol. 22, No 2

Crane D., Invisible colleges. Diffusion of knowledge in scientific communities. University of Chicago Press, Chicago 1972

${ }^{19}$ D. Rafinejad, Innovation, product development and commercialization. Case studies and key practices for market leadership, J. Ross Publishing, Fort Lauderdale 2007, s. 121.

${ }^{20}$ G. Kozmetzsky, F. Williams, V. Williams, New Wealth. Commercialization of Science and Technology for Business and Economic Development, Praeger, London 2004.

${ }^{21}$ F. Betz, Academic government industry strategic research relationships, ,Journal of Technology Transfer" 1997, vol. 22, No 2. 
Debackere K., Veugelers R., The role of academic technology transfer organizations in improving industry science links, „Research Policy” 2005, vol. 34, issue 5

Deklaracja lizbońska, Uczelnie Europy po 2010 roku: różnorodność ze wspólnym celem, http://www.bwm.pk.edu.pl/Deklaracja_Lizbonska.pdf

Etzkowitz H., Leydesdorff L., The endless transition: A 'triple helix' of university-industry-government relations, „Minerva” 1998, No 36

Fiske A.P., Relativity within moose culture: four incommensurable models for social relationships, „Ethos” 1990, vol. 18

Kozmetzsky G., Williams F., Williams V., New Wealth. Commercialization of Science and Technology for Business and Economic Development, Praeger, London 2004

Madanmohan T.R., Navelkar S., Roles and knowledge management in online technology communities: an ethnography study, „International Journal of Web Based Communities" 2004, vol. 1 (1)

Mairesse J., Mohen P., To be or not to be innovative: an exercise in measurement, NBER Working Paper 2001, No 8644

Miller R.C., Le Boeuf B.J., Developing University - Industry Relations. Pathways to Innovation from the West Coast, John Wiley \& Sons, San Francisco, 2009

Otto J., Marketing relacji. Koncepcja i stosowanie, C.H. Beck, Warszawa 2004 Porter M.E., Location, competition, and ecnonomic development: local clusters in a global economy, „Economic Development Quarterly” 2000, vol. 4 (1)

Rafinejad D., Innovation, product development and commercialization. Case studies and key practices for market leadership, J. Ross Publishing, Fort Lauderdale 2007

Ranga M., Etzkowitz H., 'Triple helix systems: an analytical framework for innovation policy and practice in the knowledge society, ,Industry and Higher Education" 2013, No 27 (4), Special Issue.

Rappa M.A., Debackere K., Technology communities and the diffusion of knowledge, „R \& D Management” 1992, vol. 22 (3)

Robin S., Schubert T., Cooperation with public research institutions and success in innovation: evidence from France and Germany. Karlsruhe, April 2010, [w:] Innovation Systems and Policy Analysis, Fraunhofer ISI Discussion Papers 2010, No 24

Rydel M., Ronkowski C., Marketing partnerski, „Marketing i Rynek” 1995, nr 9

Shane S., Technology and innovation management, John Wiley \& Sons, West Sussex 2008 
System transferu technologii i komercjalizacji wiedzy w Polsce - sity motoryczne i bariery, red. K. Matusiak, J. Guliński, PARP, Warszawa 2010

Trzmielak D., Grzegorczyk M., Technology marketing - the use of relationship marketing principles in the process of international commercialization, [w:] Rozvoj marketingu v teórii a praxi Marketing Development in Theory and Practice, red. J. Striss, EDIS - Vydavatel'stvo Žilinskej Univerzity, Žilina 2010 